\title{
Müziğin Kökenine Yönelik Arkeolojik Bir Değerlendirme*
}

\author{
An Archeological Evaluation of the Origins of Music
}

Çağatay Yücel ${ }^{\mathrm{i}}$

i Dr. Öğr. Üyesi, Dicle Üniversitesi, Edebiyat Fakültesi, Arkeoloji Bölümü, https://orcid.org/0000-0002-7997-7505

öz

Müzik, evrensel ve felsefesi gereği büyüleyici bir konudur. Müzik, insanlık tarihine ve kültürlerine dair kesintisiz bir süreç sunar. Müziğin kökeni insanın tarihi kadar eskidir. Müzik Soyut ve somut olarak hayatın her alanında kendine yer edinir. Gündelik yaşamın birçok alanını kaplar, insanın günlük yaşamında önemli rol oynar. Organoloji nin geleneksel olarak merkezi bir ilke olduğu müzik arkeolojisi, bu araştırma alanında en güçlü çıkarlara sahiptir. Bu çalışmada müzik enstrümanlarının tarihöncesi ve tarihsel süreci ortaya koyulmaya çalışılmıştır. Bu makale müzik arkeolojisiyle ilgili değerli çalışmaları odak haline getirmeyi hedeflemektedir. Bu enstrümanları kimler, nerede, neden ve ne zaman yaptılar gibi sorulara yönelik kuramsal çözüm bulunmaya çalışılmıştır. Bu çalışmadaki müzik enstrümanları Orta Paleolitik dönemden antik çağ arasındaki zaman dilimlerine tarihlenmektedir. Çağlarla ilgili olarak enstrümanlardan örnekler verilmiş ve bir bütünlük oluşturulmaya çalışılmıştır. Ahşap, bitkisel temelli organik aletlerin günümüze kadar gelemediğinden söz konusu bu aletlere değinilmemiştir. Tunç Çağına gelindiğinde müzik enstrümanları çok daha çeşitlilik göstermeye başlar. Müzik gündelik hayatın önemli bir parçası haline gelir. Antik Grek tasvirlerinde ise müzikle ilgili birçok mitolojik tasvir bulunmaktadır.

Anahtar Kelimeler: Müzik, Müzik Arkeolojisi, Paleolitik flüt, Alet, Boğaböğürten.

\section{ABSTRACT}

Music is a universal and fascinating subject due to its philosophy. Music offers an uninterrupted process of human history and cultures. The origin of music is as old as the history of man. Music Takes Its Place in all aspects of life in an abstract and concrete way. Music occupies many areas of everyday life, plays an important role in a person's daily life. Music Archaeology, where organology has traditionally been a central tenet, has the strongest interests in this field of research. In this study, the prehistoric and historical process of musical instruments is tried to be revealed. This article aims to bring valuable studies in music archeology into focus. It has been tried to find a theoretical solution to the questions such as who, where, why and when they made these instruments. The period of musical instruments in this study is dated from the Middle Paleolithic to the time periods between antiquity. Examples of instruments related to the era were given and an attempt was made to establish integrity. Wood, plant-based organic tools can not come to the present day, these tools in question have not been mentioned. When it comes to the Bronze Age, musical instruments begin to show much more diversity. Music becomes an important part of everyday life. There are many mythological descriptions of music in ancient Greek depictions.

Keywords: Music, Music Archeology, Paleolithic flute, Instrument, Bullroarer.

\footnotetext{
*Lokman Hekim Dergisi, 2021; 11 (1): 16-29

DOI: $10.31020 /$ mutftd.812848

e-ISSN: 1309-8004, ISSN 1309-761X

Geliş Tarihi - Received: 19 Ekim 2020; Kabul Tarihi - Accepted: 26 Kasım 2020

Iletişim - Correspondence Author: Çağatay Yücel <cagnar21@gmail.com >
} 


\section{Giriş}

Müzik aleti olabilecek paleolitik nesneler beş ana türe ayrılır. Birincisi olarak en sık kullanılan tür, flüt veya boru biçimli olanlardır. İkinci olarak, genellikle "falanks (parmak) flütleri" olarak yorumlanan delikli parmak kemikleridir. Falanks kemikleri ya da parmak kemikleri omurgalı hayvanların ellerinde ve ayaklarındaki parmaklarda bulunan kemiklerdir. Çalışmamızdaki Paleolitik döneme ait flütlerin yapım tekniği olarak bu tür flütlerden söz edilmiştir. Üçüncü bir tür aerofon, yani boğa böğürten olarak yorumlanan nesnelerdir. Dördüncüsü paralel oluklarla çentiklenmiş bazı kemik parçalarıdır, bunlar da törpüler olarak işlev görmüş olanlardır. Son olarak beşincisi ise, mağaraların kendisinin ve mağaraların içyapısındaki özelliğinin dolayı akustik ses aracı olarak kullanıımasıdır. ${ }^{1}$ Beşinci durum haricinde, Paleolitik dönemden bilinen veya tanınmış ses üreticilerinin tüm örnekleri kemikten yapılmıştır. Bu, yakın veya daha geç tarihteki avcı toplayıcı vakalarının etnografik örneklerine ters düşer; yakın tarihteki ses (müzik) üreticilerinin üretim için kemik kullanımları nadirdir. Müzik enstrümanları olarak doğal olarak oluşan bitki bazlı (veya diğer organik) ürünlü malzemeler tercih edilmiştir . ${ }^{1}$

Tarih öncesi ve günümüzdeki flütler, hava akımını bir kenar üzerinden 'keserek' ses üretirler; bu da türbülans ve hava titreşimlerine neden olur. Açık veya kapalı borularda titreşim frekansı, borunun uzunluğuna ve çapına bağlıdır. Daha hızlı üfleyerek, frekansta ilk yüksek oktav elde etmek için ses iki katına çıkar. Artan hava akışının yanı sıra diğer üfleme teknikleri ile parmak delikleri olmadan basit borularda bile farklı yüksek aralıklarla ses ya da müzik üretilir. Ses üretmek için hava akımını kesmenin temelde iki farklı yolu vardır. Bunların ilki bir borunun ucuna veya bir gövdesindeki bir deliğe (enine oluklar) üfleme yolu. íkincisi hava akışını ses deliğinin eğimli kenarına yönlendiren hava kanalına üfleme yoludur. İlk tür basit bir yapıya dayalıdır, ancak çalınması daha zordur çünkü çalanın hava akımını kontrol etmesi gerekir, böylece hava kesen kenara tam olarak hava akımının çarpması gerekir. Fipple Flüt olarak adlandırılan ikinci tip, kanal hava akışını yönlendirdiği için çalmak daha kolaydır. Ancak, bunu yapmak çok daha zahmetlidir. Çünkü boruya bir tıpa koymak, hava kanalını tıpa ve/veya borunun iç duvarına hava yönlendirilecek şekilde havayı kesmek ve boru gövdesindeki deliğin eğimli kenarına hava akımını üflemek gerekir. ${ }^{1}$

Müzik son derece duygusal bir konudur ve müziğin kökenleri binlerce yıldır insanları büyülemiş ve kökeni tarihöncesine dayanmaktadır. Bu nedenle, müziğin tek güvenilir kanıtını temsil eden bu en eski korunmuş enstrümanlar hakkında daha fazla bilgi edinmek oldukça ilgi çekicidir. Bunları ilk kim icat etti ve neden yaptılar? Flüt yapımında ne gibi teknikler kullanmışlardır? Ne tür flütler yaptılar? Hangi sesi ürettiler? Ve en ilgi çekici olanı, hangi müziği çalıyorlardı? Gibi ilgi çekici sorular yer alıyor. Hiç şüphe yok ki müziğin başlangıcı Paleolitik çağa, on binlerce yıl öncesine uzanıyor. Asıl mesele ise müzik olarak kullanılan bu enstrümanların ne kadar geriye gittiğidir.

\section{METOT}

Bu çalışmada, nicel ve nitel araştırma yöntemi olan tasvirsel analizler kullanılııştır. Çalışmanın konusu ile ilgili bilimsel yayınlar araştırılmış olup, Avrupa, Uzak Asya ve Yakındoğu uygarlıklarının arkeolojik yüzey araştırması ve kazılar sonucu ele geçen materyallerin yayınlarından yararlanılmıştır. Bu çalışmanın, müzik arkeolojisine ilgi duyan araştırmacılara müziğin kökenine ve nefesli çalgıların tarihsel süreci ile ilgili kaynak olması hedeflenmiştir. Bu bakımdan kronolojik olarak her çağ ile ilgili örnekler verilmiştir.

\section{BULGULAR}

\subsection{Orta Paleolitik Çağ’da Müzik Aletleri}

Libya'da Haua Fteah'ın Orta Paleolitik seviyelerinde bulunan tek delikli uzun uyluk kemiği, McBurney tarafından 1969 yılında kırık bir flüt olarak yayınlandı. Kemiğin kırık kenarlarından biri içbükeydir ve birinciyle 
hizalanmış ikinci bir deliğin kalıntısı olarak yorumlanmıştır. Bu nesnenin üzerindeki delik, etobur deliklerin ortak bir özelliği olan çukur kenar boşluklarını gösteren taş alet izlerinin yokluğuna ve delik duvarlarının morfolojisine işaret eden Davidson (1991), kemik üzerindeki deliklerin bir etobur deliği olarak yorumlamış kemiğin bir müzik enstrümanı olmasına karşı çıkmıştır. ${ }^{2}$ Bir Mousterian endüstrisi ve bir Üst Pleistosen döneminin faunasıyla ilişkili olarak bulunan ve bir dizi derin alt paralel olukları gösteren, Belçika'nın Schulen kentinde bir mamuta ait uzun bir kemik parçası ise, Huyge (1990) tarafından kazınmış bir idyofon", ses üretmek için ritmik olarak kazınmış oluklu bir yüzeye sahip müzik aleti olarak tanımlanmıştır. ${ }^{2}$

Söz konusu arkeolojik kanıtlar bilinen en eski müzik aletlerinin yaklaşık olarak 40 bin yıl önce arkeolojik kayıtlarla ortaya çıktığını doğrulamaktadır. Bir milyon yıl önce, Geç Aşölyen kültüründe (800-250 bin yıl önce) homininilerin beyin büyümesinde evrimsel olarak bir ilerleme meydana geldi. Bu, hâlihazırda devam etmekte olan müzikal gelişmelere paralel olarak, ses-anatomisinin sinirsel dokularla birlikte gelişmesini de beraberinde getirdi ve bu da atalarımızın her zamankinden daha sözel olarak iletişim kurmasını sağlamaya yaradı. Anatomik yapıdaki evrimleşmeyle alt gırtlaklar yoluyla boğaz ve ağız tarafından oluşturulan ses yansıtma odası genişlemiş oldu, bu da ses aralıklarını ve üretilebilir sesleri büyük ölçüde geliştirmiş oldu. ${ }^{3}$ Bunun meydana geldiğinin ilk kanıtı Homo ergaster /erectus'tadır. Aynı şekilde homininilerdeki bu ortak evrim, özellikle seslerinin duyulması açısından, işitsel algının altında yatan nöral ve anatomik mekanizmaları da hassaslaştırmıştır. Tek delikli uzun uyluk kemiği radyokarbon yöntemi ile 36.000 yıllık olarak değerlendirildi. Buna ek olarak, Üst Paleolitik'in sonraki evrelerinde, özellikle Gravettian ve Magdalenian olmak üzere, nispeten nadir bulunan başka kemik yivleri de ele geçmiştir. ${ }^{4}$

19. yüzyılın sonlarında ve 20. yüzyılın başlarında dönen en temel tartışma, dilin fonetik yapısı ve müziğinin kökeni etrafında dönüyordu ve hangisinin daha önce gerçekleştirildiği merak konusuydu. Biyolog Charles Darwin, evrimi eşeyli seçilim yoluyla kabul etmesine uygun olarak, müziğin kuş şarkısına benzer bir kur yapma gösterisi olarak evrimleştiğini; konuşmanın müzikten kaynaklandığını iddia ediyordu. ${ }^{5}$ Bununla birlikte bu tartışma ve beraberinde ortaya çıkan merak ilgiyi arkeolojik kazılara yönlendirmiş, müzik aletlerinin tarihi ve özellikle tarih öncesi kökenine doğru araştırmalara yöneltmiştir. Keşfedilebilir en eski müzik araçları binlerce yıl boyunca kemik malzemeleri olarak kazılar neticesinde ele geçmiştir. Ayrıca tarihi ve kutsal kitaplara ait kayıtlarda da, günümüzden 5.000 yıl öncesine dayanan müzik aletlerinden söz edilmekteydi. ${ }^{6}$

Bilim insanları, yaklaşık olarak 800-600 bin yıllık fosil kalıntılarındaki çıkarımlarına göre Homo Heidelbergensis'in, Homo neandertal'lerin, Homo Denisovalar'ın ve modern insanın atası olduğu düşünülen Hominid'lerin, günümüz insanların üretebileceği vokal ses türlerini az ya da çok çıkarabiliyorlardı ve seslendirmelerinde çoğunlukla yönetici kontrole sahiptiler. Aynı zamanda Homo Heidelbergensis'in soyundan gelen Homo Neandertal'lerin, erken dönem Homo Sapiens'in dilbilimsel-vokal kapasitelerine benzer özelliklere sahip olup olmadıkları bilim adamlarınca hala tartışılmaktadır. Bununla birlikte her iki türün anatomik olarak modern ses müzikalitesine sahip olması da olasılık dahilindedir. ${ }^{6}$ Ancak Homo Neandertaller kişisel süs eşyaları ve kemikten alet yapmış olsalar da müzik yapımlarına ait herhangi bir bulgu şuana kadar bulunamamıştır. Üst Paleolitik Çağ'dan önce durum çok farklıydı. Bu dönemden sanat pratik olarak bilinmemektedir, ancak bu var olmadığı anlamına gelmemektedir. Çünkü geçmişte şimdi de olduğu gibi kemikten olduğu kadar içi boş bitki saplarından da flütler yapılmış olmalıydı. Ancak bunlar organik olduğundan günümüze kadar gelememişlerdir. ${ }^{6}$

Slovenya'da Divje Babe mağarasında yapılan arkeolojik kazılarda genç bir mağara ayısının uyluk kemiğinden yapılan flüt Orta Paleolitik döneme tarihlenmektedir ve bu nedenle şuana kadar dünyadaki en eski enstrümanı temsil ettiği kabul görmektedir. ${ }^{2-4-7}$ Nesnenin Neandertaller tarafından flüt olarak kullanılması,

\footnotetext{
* Idyofon, tınılı bir katı cismin (örn. ahşap, metal ya da taş) titreşmesiyle ses çıkaran çalgıların genel adıdır.
} 
büyük bir ses getirdi. Genç bir ayının uyluk kemiğinden yapılmış, yaklaşık $37 \mathrm{~cm}$ uzunluğunda bir flüt parçası olduğu ve Batı müziğinin dayandığı yedi nota kalıbının tamamının çalınabileceği önerileri öne sürüldü. ${ }^{2}$ Diğer yandan ise bulgunun bir flüt olarak yorumlanması ile ilgili kuşkular hala devam etmektedir. Çünkü buluntu Geissenklösterle'deki flüt ve diğer kemik ürünlerinden neredeyse 10.000 yıl daha geriye gitmektedir (Şekil 1). Deneysel arkeoloji alanında bazı uzmanlar bu flütlerin gerçek olup olmadığı ile ilgili çalışmalar yapmıştır. Bunlardan biri olan Gustaf Alleng, orijinal Sloven ayı kemiği flütünün nasıl bir müzik enstrümanı olduğu öngörüsüne dayanarak kendi yaptığı bir modeli kullanır. Bunun için orijinal esere bağı kalarak parmak deliklerini standartlaştırmak için yaptığı özel bir metal kalibrasyon kuralı kullanır. Bu yöntemle (teknik olarak balmumu bloğu ilkesini uyguluyor) müzikal perdeyi veya duyulabilir frekansı ve de enstrümanın makamını belirlemeye çalışır. Yeniden yapılandırma ile orijinal Divje Babe flütünün nasıl görüneceğine, sesinin nasıl çıkacağına ve nasıl çalındığına dair bulgunun (nefes çıkışı ve parmakların yerleştirme düzeninin) yeniden yorumlanmasıdır. Gustaf, arkeolojik kayıtlardan algılanan flüt örneklerini deneysel arkeoloji yöntemiyle doğal malzemeler ve üzerinde çalışmak için orijinal ve modern araçların bir karışımını kullanarak hem bu flütleri kopyaladı hem de yeniden oluşturdu. Divje Babe rekonstrüksiyonu onun öznel yorumudur. Ayı uyluk kemiği yerine silindir olarak koyun uyluklarını kullandı. Ürettiği bu flütün bir şekilde av düdüğü olduğu yönünde görüş bildirmiştir. $^{7}$

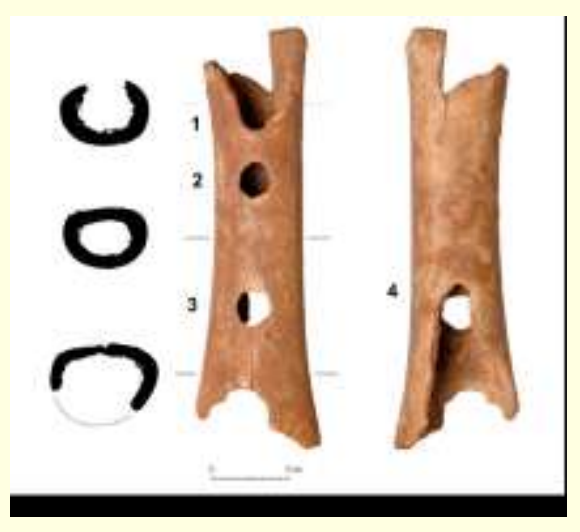

Şekil 1. Orta Paleolitik (GÖ 200.000-40.000) Döneme ait genç bir mağara ayısının uyluk kemiğinden yapılan flüt (Turk, Turk ve Otte 2020: 2$)^{8}$

\section{2 Üst Paleolitik Dönemde Müzik Aletleri}

Avrupa'da, Almanya'daki Geissenklösterle mağarasında bulunan insan bilincinin bir sanat eseri olarak üretilen ilk müzik aleti, Üst Paleolitik'in başlarına tarihlenen ve Aurignacian kültüründen kalma kemik bir flüttür. Almanya'nın güneybatısında bulunan Geissenklösterle Mağarası, mamut fildişinden oyulmuş örneklerin dışında Aurignacian aerofonları ve bir kuğunun (Cygnus cygnus) ulnae (ön kol kanat) kemiğinden yapılmış, üzerinde üç deliğin bulunduğu 37 bin yıllık bir flüt ele geçmiştir. ${ }^{9}$ (Şekil 2)

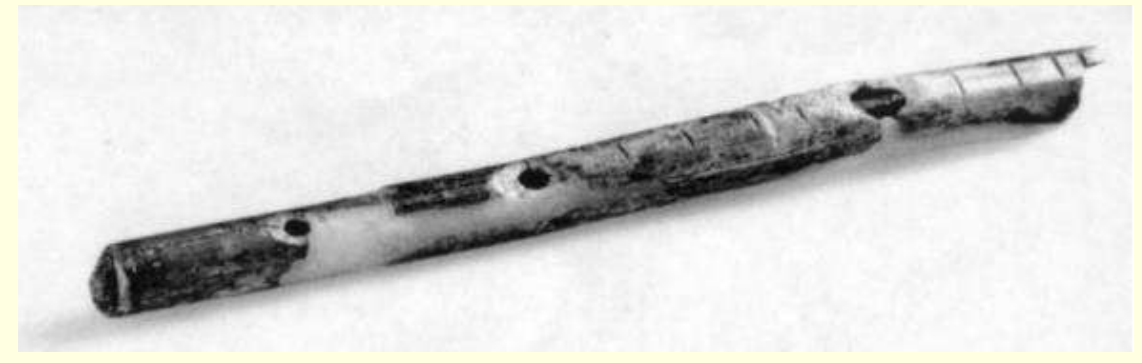

Şekil 2. Geissenklösterle flütü (Münzel, Seeberger ve Hein 2002: 115) .9

Bir başka örnek ise güney Fransa'da Isturitz Mağarasında Gravettian dönemine ait tabakada 20'den fazla kemik boru parçasıdır. Daha sonra bunların akbaba ulnaesından yapıldığı tespit edildi. ${ }^{10}$ Arberoue Vadisi'ndeki 
Gaztelu Dağı'nda bulunan Isturitz Mağarası, Orta ve Üst Paleolitik arkeolojik seviyeleri içeren, FrancoCantabrian Atlantik bölgesindeki en önemli tarih öncesi alanlardan biridir. Müzik kalıntılarının öne çıktığı önemli arkeolojik kalıntılara sahiptir. Bu nesneler çoğunlukla Gravettian seviyesine aittir, ancak Aurignacian'dan Magdalenian'a kadar olan buluntular da ele geçmiştir. ${ }^{11}$ Buluntuların sayısı açısından, Fransa'daki Isturitz mağarası birinci sırada yer alıyor. Fransa'da Isturitz'de bulunan bir başka buluntu dizisi 20 kadar antik kuş-kemik flütünden oluşur, ancak bunların yaşı günümüzden önce 35-32 binden 17-11 bine kadar değişmektedir (Şekil 3). Bu nedenle, müziğin tek güvenilir kanıtını temsil eden bu en eski korunmuş enstrümanlar hakkında daha fazla bilgi edinmek oldukça ilgi çekicidir. Bunları kim icat etti ve neden yaptı? Flüt yapımında neler vardır? Ne tür flütler yaptılar? Hangi sesi ürettiler? Ve en ilgi çekici olanı, hangi müziği çalıyorlardı? Soruları oldukça merak uyandırıyor.

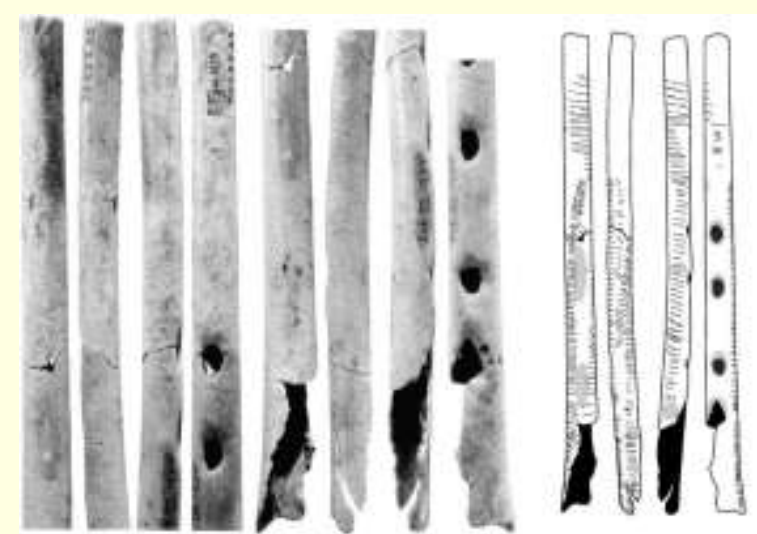

Şekil 3. Isturitz'den Gravettian kültürüne ait flütler (Brade 1982:149). ${ }^{12}$

Yine Üst Paleolitk dönemine ait Isturitz mağarasında Orta Aurignacian dönemine ait tabakada iki flüt parçası daha ele geçti (şekil 4).
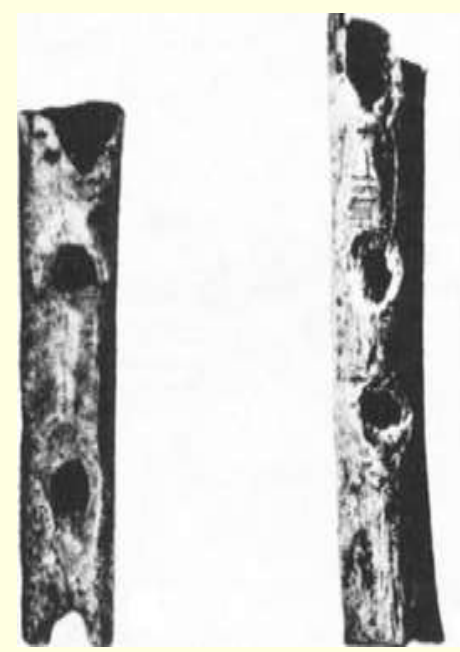

Şekil 4. Basses-Pyrenees'teki Isturitz Mağarasında bulunan iki kemik flüt. Uzunluklar 108 mm ve 92 mm(Brade 1982:149.12

Brade, Basses-Pyrenees'te Isturitz Mağarasında toplam on iki kemik parçasını müzik aletleri olarak görüş bildirir. Bu kemik parçaları, her biri birden fazla deliğe sahip, yan yana yerleştirildiğinde benzersiz bir grup oluştururlar. Bu flütler, her ne kadar hepsi birer kemik parçası olsa da aynı uzunluklara sahip değillerdir. Aynı zamanda bu flütler benzer bir kırılma yapısına da sahiptirler. Tek tek nesnelerin kırık noktaları birbirine o kadar benzer ki, bunların kazara kırılmaları imkânsız gibidir. Böylece bu kemik grubu aletlerin birer müzik enstrümanı olduğu yönünde bilim adamlarınca görüş bildirilmiştir. ${ }^{12}$ 
Üst Paleolitik Döneme ait başka bir müzik aleti güneybatı Almanya'daki Svabya Alpleri'nden gelen flüttür (Şekil 5). Burada çoğu kuş kemiğinden (ağırlıklı olarak akbaba önkol kemiği, dirsek kemiği veya kuğu kemiği); birkaç tanesi de mamut fildişinden yapılmış flütler ele geçirilmiştir. ${ }^{3}$ Avrupa'nın her yerinde olduğu gibi Almanya'da da Üst Paleolitik'in (40.000 ila 30.000 yıl önce) başlangııından bu yana sanatın gelişmesi kesintisiz devam etmiştir. ${ }^{4}$

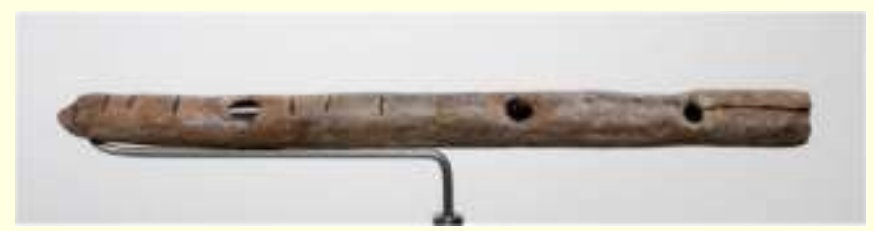

Şekil 5. Svabya Alpleri'nde Üst Paleolitik Döneme ait bir flüt (Killin 2018: 6) .3

Cro-Magnon insanları 43.000 yıl önce Afrika'dan Avrupa'ya geldiklerinde, müzikal eserler yapma ve kullanma yeteneği de beraberlerinde getirmişlerdir. Kemik ve fildişinden yapılan flüt, günümüzden 40 bin yıl önce Orta ve Üst Paleolitik arasında yer alan Chatelperronian kültürüne ait eserdir. ${ }^{6}$ Bu flüt 2008'de Almanya'nın Svabya Alpleri'nde Hohle Fels'de arkeolojik kazılarla ortaya çıkarılan grifon akbabasının (Gyps fulvus) önkol (ulnae) kemiğinden yapılmıştır: araştırmacıların adeta tam bir parça olduğunu düşündüğü flütün korunan kısmı 21,8 cm uzunluğunda ve $0,8 \mathrm{~cm}$ çapındadır (Şekil 6).

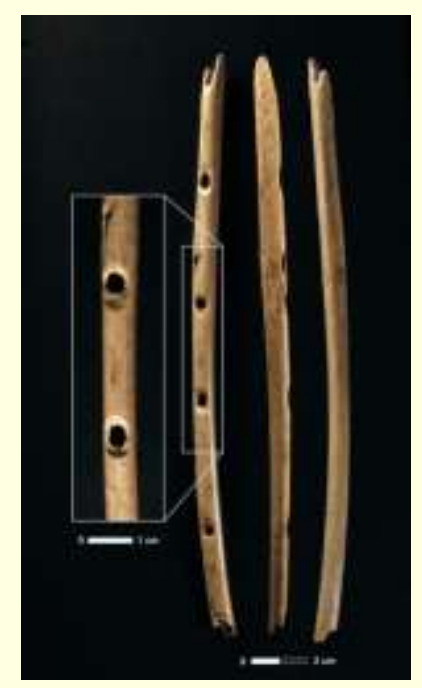

Şekil 6. Cro-Magnon insanına ait Hohle Fels'de ele geçen kemik flüt (Conard, Malina ve Münzel 2009: 1). ${ }^{13}$

Flütün gövdesi inceltilmiş bir alet kullanılarak düz bir şekilde kazınmış ve içbükey girintilerden parmak delikleri oluşturulmuştur. Kemiğin proksimal (gövdeye yakın) ucu manuel olarak ayarlanmış, muhtemelen bir ağız deliği olarak daha iyi işlev görebilmesi için kemiğin ucuna iki $V$ şekli oyulmuştur. Parmak deliklerinin yanındaki kesik izleri, parmak deliklerinin yerleşimlerinin ölçüldüğünü gösterir, bu da flütün bu yönünün akılda bir şeyler tasarlandığını düşündürür: belki bir akort etme standardı veya alarm (uyarı) işareti. Swabian Jura'dan prehistorik flütlerin rekonstrüksiyon deneyleri, mümkün olan çok çeşitli tonlar sergiler ve bu enstrümanlar tam bir gelişmiş müzik enstrümanları olarak performans sergiledikleri anlaşılmaktadır. ${ }^{14}$ Oldowan'dan Aşölyen'e kadar taş alet tasarımında olduğu gibi, bu müzik aletlerinin yapımı da insan bilişinin ve sosyal öğrenmenin gelişmesini gösteriyor. Flütte hayvan kemiği olarak akbabanın seçilmesinin nedenleri vardır. Akbaba kemikleri sağlam, içi boş, uzun ve hafiftir, bu nedenle özellikle flütler için hammadde olarak uygundurlar. Bu flütler aynı zamanda kırılgandır ve belki de yalnızca mağara çevresinde sağlam kalabileceklerdi. Kısa ömürlü olan daha kolay işlenebilen malzemeler (örneğin bambu, kamış, ahşap veya deniz yosunu boruları) zamana karşı dayanıklı olmayan malzemeler ile yapılan flütler kuş kemiği ve fildişi flütlerden daha eski de olabilir. Ancak organik özelliklerinden dolayı günümüze ne yazık ki ulaşamamışlardır. 
Etnografik kayıtlar sazlık, su kabağı, hayvan derisi ve ağaç kabuğu gibi doğal, kısa ömürlü malzemelerden yapılmış çeşitli müzik aletlerin yanı sıra bizon boynuzu, deniz kabuğu gibi çok az değişiklik gerektiren veya hiç değişiklik gerektirmeyen aletlerden yapılmış enstrümanlardan söz eder. Parmak delikleri, ses düzenleme düğmesi mekanizmaları veya benzeri çeşitli üflemeli çalgılar - boynuz, ahşap ve fildişi oluklar -Afrika'da Sahra'da günümüzde de oldukça yaygındırlar. ${ }^{13}$

Morley şimdiye kadar arkeologlar tarafından ortaya çıkarılan tarih öncesi müzik aletlerinin araştırma ve envanterini ortaya çıkarmıştır. 104 kuş kemiği ve fildişinden flütün yanı sıra ren geyiğine ait delikli olan ön ayak parmak kemiklerinin de müzik enstrümanı olduğunu iddia eder. ${ }^{1-16}$ Aynı zamanda boğa böğürten ve farklı biçimlerdeki vurmalı çalgı aletlerinin envanterini de müzik aletlerinin arasına alır. Kuhn ve Stiner, çeşitli çağdaş müzik kültürlerinde bulunan raspaları anımsatan yaklaşık 35-32 000 bin yıllık farklı toynaklı biçiminde bir kemiği müzik aleti olarak tanımlar. ${ }^{15}$ Bu durumda Üst Paleolitik toplumların avlanma öncesi müzik aletleri ile ayinler gerçekleştirmiş olabilecekleri yorumunu öne sürebiliriz. Avın başarı ile sonuçlanmasına dair bir tür müzikal ritüel hazırlığı olabilirler. ${ }^{3-16}$

Kuş kemiği ile karşılaştırıldığında, fildişi flüt üretimi daha fazla beceri, hassas çalışma ve çaba gerektirir. Akbaba ve kuğunun önkol kemiği ve dirsek kemiği doğal olarak içi boş ve zaten uygun bir boyuttadır, aynı zamanda hafif, sağlamdır ve bu nedenle büyük boy, katmanlı ve çalışması zor olan fildişi ile karşılaştırıldığında işlenmesi daha kolaydır. Fildişi Flüt üretimi ise şunları gerektirir: Fildişi kesiti doğru uzunlukta kesilmeli, daha sonra uzunluğu boyunca iki parçaya bölünmeli, çekirdek katmanlar çıkarılmalı ve daha sonra oluğun iki yarısı yeniden yerleştirilmeli ve borunun ses çıkarması için hava geçirmez bir damgalama oluşturması için bağlayıcı madde ile birbirine bağlanmalıdır. ${ }^{1-16}$

Fildişi flüt üretimi, Üst Paleolitik müzik teknolojilerinin olgunluğunu ve gelişmişliğini gösterir. Değerli kaynakların müzik teknolojilerine olan bağlılığı müziğin antik insanlar için gerçekten önemli olduğunu gösteriyor. Potoka Mağarası'nda (Slovenya) kazılar esnasında çıkarılan başka bir flüt, çok sayıda işlenmiş ayı kemiği ile birlikte bir ayının uyluk kemiğinden üretilmiş olup, ikinci Aurignacian (GÖ 35.000) dönemine tarihlenir. Bu nesne, oldukça eşit aralıklarla yerleştirilmiş birkaç delik sergiler. ${ }^{12}$ Mağarada üzerinde bir veya daha fazla delik bulunan mağara ayılarına ait çene kemikleri bulundu. Farklı korumalara sahip sekiz çene kemiği ortaya çıkarıldı. Bir çene kemiğinin üzerinde sıralı delikler vardır. Hiç şüphe yok ki, bu delikler insanlar tarafından yapıldı, çünkü etoburlara ait kemirme izleri kemik üzerinde rastlanmamıştır. Üç delikli ilk çene kemiği bulunduğunda, bunun belirli bir tür flüt olduğu önerilmişti (Şekil 7). İlginç bir şekilde, bu tür çene kemiği sadece Slovenya Alp bölgesinde ortaya çıkmaktadır. ${ }^{17}$

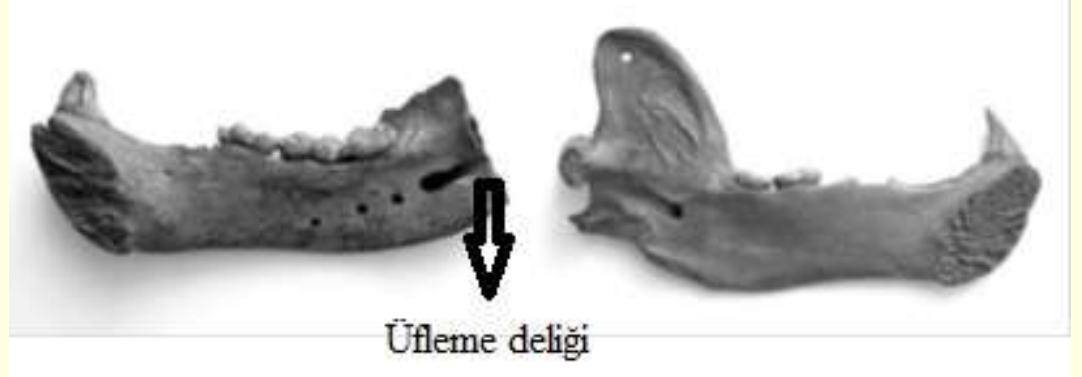

Şekil 7. Çene kanalın üzerinde üç delik bulunan mağara ayısına it bu çene bir tür flütü temsil eder. Seslerin ve müziğin daha kolay çıkması için kasıtlı olarak üst çene kemiği çıkarılmıştır (Odar 2012: 14). ${ }^{17}$

1951'de Macaristan'ın İstallosko Mağarası'nda keşfedilen ikinci Aurignacian dönemine tarihlenen bir başka flüt, Paleolitik dönem müzik enstrümanlarından en ilginci olarak kabul edilir. ${ }^{12}$ Maksimum 107 mm 
uzunluğunda, sırt yüzeyinde iki delik bulunur. Yakınsal uçta bulunan delik sığ krater benzeri bir çöküntü ile temsil edilir (Şekil 8). Birbirine yakın duran ve radyal yönde ilerleyen 1-2 cm uzunluğunda çentiklere sahiptir. Uzak uçta daha büyük bir açıklıkla, 10 ila $13 \mathrm{~mm}$ yarıçaplı, düzensiz bir çevreye sahip olan ve orijinal olarak oval bir şekilde toplamda üç deliğe sahiptir. ${ }^{12}$
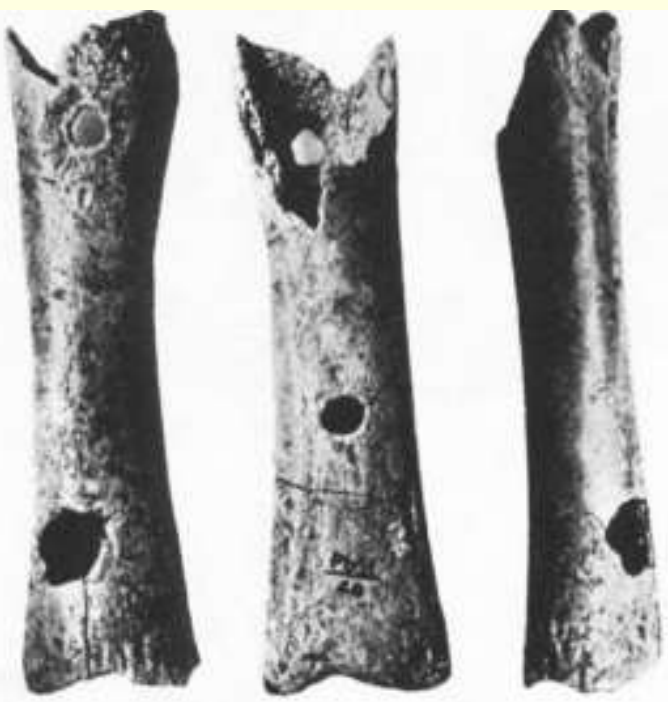

Şekil 8. İstallosko Mağarasında bulunan flüt kemik (Brade 1982: 149).12

Üst Paleolitik Çağ'da en eski müzik aletlerinden biri kabul edilen flüt dışındaki diğer bir enstrüman bullroarerlerdir. Diğer bir adıyla "boğa-böğürten" enstrümanıdır. Flüt veya boru tipi enstrümanlara göre sayısı az olsa da bu dönemde üretildikleri kazılar sonucunda netleşmektedir. Bu enstrüman, bir kordonun ucundaki düz delikli bir ahşap veya kemikten oluşur, bu da dairesel bir hareketle büküldüğünde bir uğultu sesi çıkarır. ${ }^{18}$ Günümüzde bazı Avustralya Aborjinleri doğanın doğal seslerinde meydana geldiklerine inandıkları ruhları taklit etmek için bu aleti kullanırlar. Günümüzde yine birçok Kuzey Amerikalı grup, Yeni Zelanda'nın Maurileri, Yeni Gine ve İskandinavya Samileri arasında da bu alet hala kullanılmaktadır. Malezya federasyonunda yaşayan halklar, hayvanları tarlalardan uzaklaştırmak için yine bu enstrümanı kullanırlar. ${ }^{1} \mathrm{Bu}$ delikli kemik parçaları, Aurignacian kültürü (MÖ 38000-28000) ile Gravettian kültüründe (MÖ 29000-22000) ele geçmiştir (Şekil 9 ). Bu örneklerin bir sonucu olarak, çok sayıdaki Paleolitik bullroarerlerin sırtlan vb yırtıcıları uzaklaştırmak amacıyla üretildikleri sonucuna varılabilir.

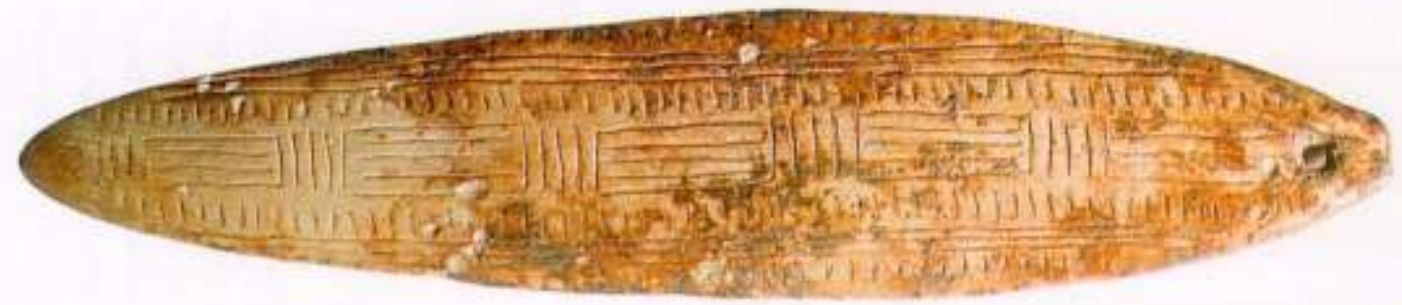

Şekil 9. Magdalenian Kültürüne ait bullroarer (boğa-böğürten) MÖ 17-10 bin. 180 mm uzunluk, 40 mm genişlik (Morley 2003:36). ${ }^{1}$

\subsection{Neolitik Çağ Flütleri}

Neolitik döneme ait olarak bugüne kadar yayınlanan flütlerin değerlendirmesini yapmak çok daha kolaydır. Neolitik Döneme ait en ünlü örnek, Danimarka'nın Bornholm adasında bulunan kemikten bir flüttür (Şekil 10). Bu bulgunun arkasında oval şekilli bir hava deliği ve üç parmak deliği olan yivlerin varlığının Tunç Çağı'na 
kadar uzandığı görülmüştür. Üstelik bu buluntu, diğer birçok tarihlenemeyen buluntular için karşılaştırmalı bir parça olması yönünden de önemlidir. ${ }^{12}$

Bir başka Neolitik döneme ait kemik flüt, Çek Cumhuriyeti'nde Moravsky Krumlov kasabasında ele geçen başka bir kemik parçasıdır (şekil 11). Flüt, 1912'de 30 adet kabuk boncukla birlikte bir mezarda ele geçirilmiştir. ${ }^{12}$
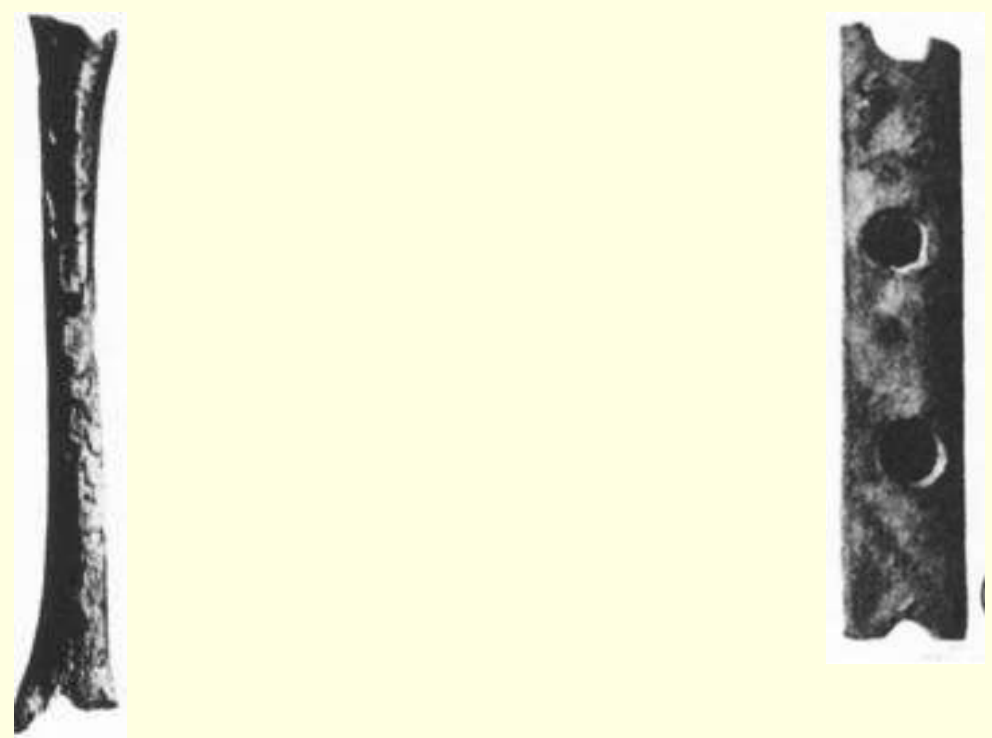

Şekil 10. Bornholm'da ele geen Neolitik Dönem'e ait kemik flüt. Uzunluk 142 mm (Brade 1982: 149). ${ }^{12}$
Şekil 11. Moravsky Krumlov Neolitik flütü. Uzunluk 63 mm (Brade 1982: 149)..$^{12}$

Çin'in Henan eyaletindeki erken Neolitik Jiahu sahasındaki kazılar esnasında çok notalı müzik aletleri ele geçirildi. jiahu, MÖ 7000'den MÖ 5700'e kadar kesintisiz bir yerleşim yeridir. ${ }^{19}$ Radyo karbon tarihli kazı tabakasında 30 parça ile birlikte, zarif bir şekilde yapılmış altı kemikten tüm halde flütler ele geçirilmiştir. Flütler, Japon turnasının dirsek kemiğinden yapılmış olup 5, 6, 7, 8 deliklere sahiptirler (Şekil 12).

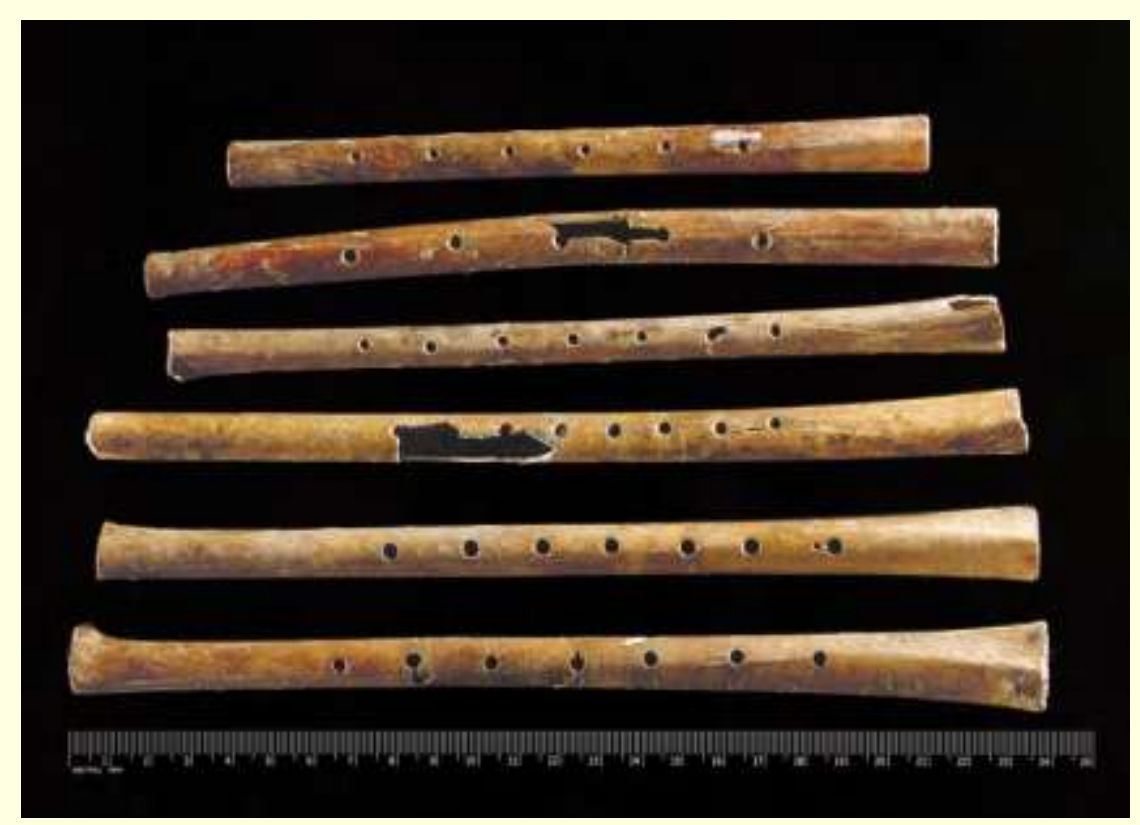

Şekil 12. Jiahu'daki mezarlardan ele geçen kemik flütleri (Zhang ve diğ. 1999: 367). ${ }^{19}$ 


\subsection{Kalkolitik Çağ'da Müzik Aletleri}

\subsubsection{Veyreau Flütü}

Bu alet düz flüt veya enine flüt olarak sınıflandırılabilir (Şekil 13). Flüt karbon izotop analizi ile tarihlendirilmesi yapılarak MÖ 3800 yılına tarihlendirilmiştir. ${ }^{20}$ Flüt, bir Griffon akbabanın önkol kanat kemiğinden (ulnae) yapılmıştır. ${ }^{5}$

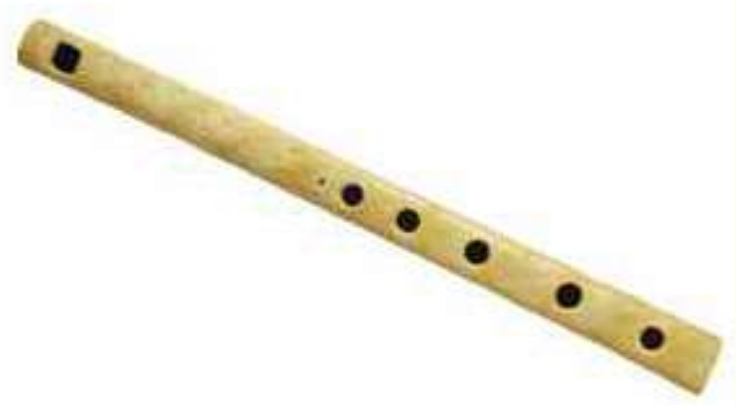

Şekil 13. Fransa Veyreau (MÖ 3800) flütü (Benito 2018: 28). ${ }^{20}$

\subsection{Tunç Çağı'nda Müzik Aletleri}

Erken Tunç Çağında yazının icadıyla birlikte Müzik Arkeolojisi ile ilgili detaylı bilgilere de erişiyoruz. Mezopotamya'da müzisyenler, tanrı ve tanrıçaları için çok farklı enstrümandan müzik aletleri yaparlardı. Müzisyenler alt tabaka sınıftan oluşurdu. Festivaller, kraliyet düğünleri, doğumlar ve cenazeler gibi durumlarda özel müzikler çalınırdı. Alt sınıfta olan bir müzisyen zamanla üst sınıf yolunda ilerleyebilirdi. Müzisyenlik sadece erkelere özgü bir meslekti. ${ }^{21}$ Ancak alanında nam yapmış kadın müzisyenler de yer almaktadır. Mezopotamya'daki müzik aletleri arasında en bilinen estrümanlar harp, lir, davul ve çıngıraklardır. Mezopotamya'da 5.500 yıllık flütler, üçgenler, telli çalgılar ve davullar da bulunurdu. Çok sayıda tablette Mezopotamya yaşamında müziğin önemini, müzik aletlerinin adlarını ve ayrıntılı bir müzik teorisinden söz eder. Sümerlerde müzik, Ur'da olduğu gibi dini törenlerde ve cenaze törenlerinde yaygın olarak kullanılmıştır. Müzisyenler tapınak görevlilerine bağlıydı ve bir hiyerarşi oluştururlardı. Mari'de, Sümer kralı Iblul-il'in sarayında (MÖ 2500) çok ünlü şarkıcı olan Ur-Nanshe, (Şekil 14) büyük şarkıcı namıyla birkaç heykelle onurlandırılmıştı. ${ }^{22}$ Betimsel mitolojik tasvirlerde hayvanların müzik çaldıkları sahneler, sadece masalları veya atasözlerini tasvir etseler de, bir tür küfürlü müziğin varlığını düşündürür. Asur kabartmalarında savaş ve kraliyetle ilgili müzik sahneleri görüyoruz.

Sir Leonard Wolley'in Ur Kral Mezarlığı'nda kazdığı binin üstündeki mezarın çoğu geç Er Hanedanlar dönemine (MÖ 2600-2400) tarihlenir. En ihtişamlı ve zengin olan mezarlara Kral Mezarları adı verilmiştir. Bunlardan üçü kraliçe Puabi'ye aittir. Kraliçe Puabi'nin mezarında bulunan bir lirin gövdesine takılmış olan, altın ve lapis lazuliden yapılmış inek başı, ahşaptan oyulmuş lirin kakma bordürlerine sahiptir. ${ }^{25}$ Woolley bu hassas buluntuları korumak ve taşımak için alçı ve erimiş parafinden yararlanmıştır (Şekil 15). ${ }^{22}$ 


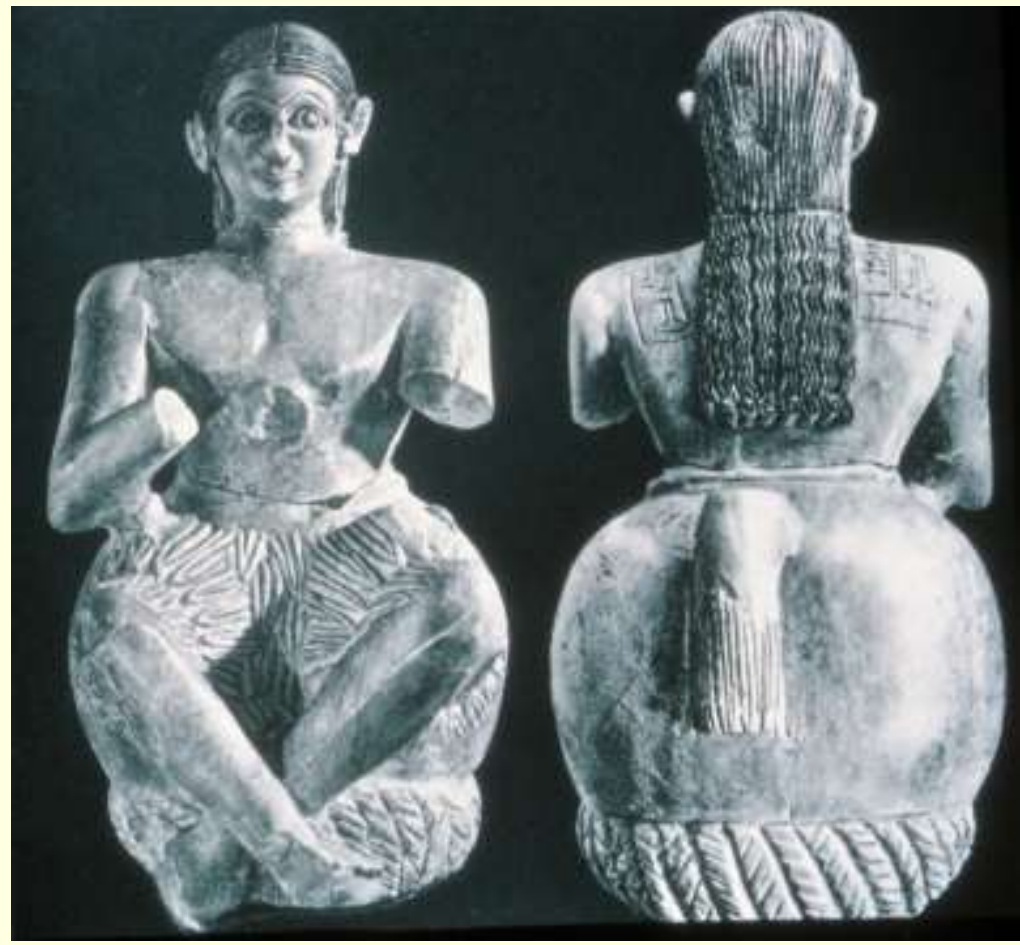

Şekil 14. Büyük şarkıcı Ur-Nanshe heykeli (van Dijk 2013: 13). ${ }^{23}$
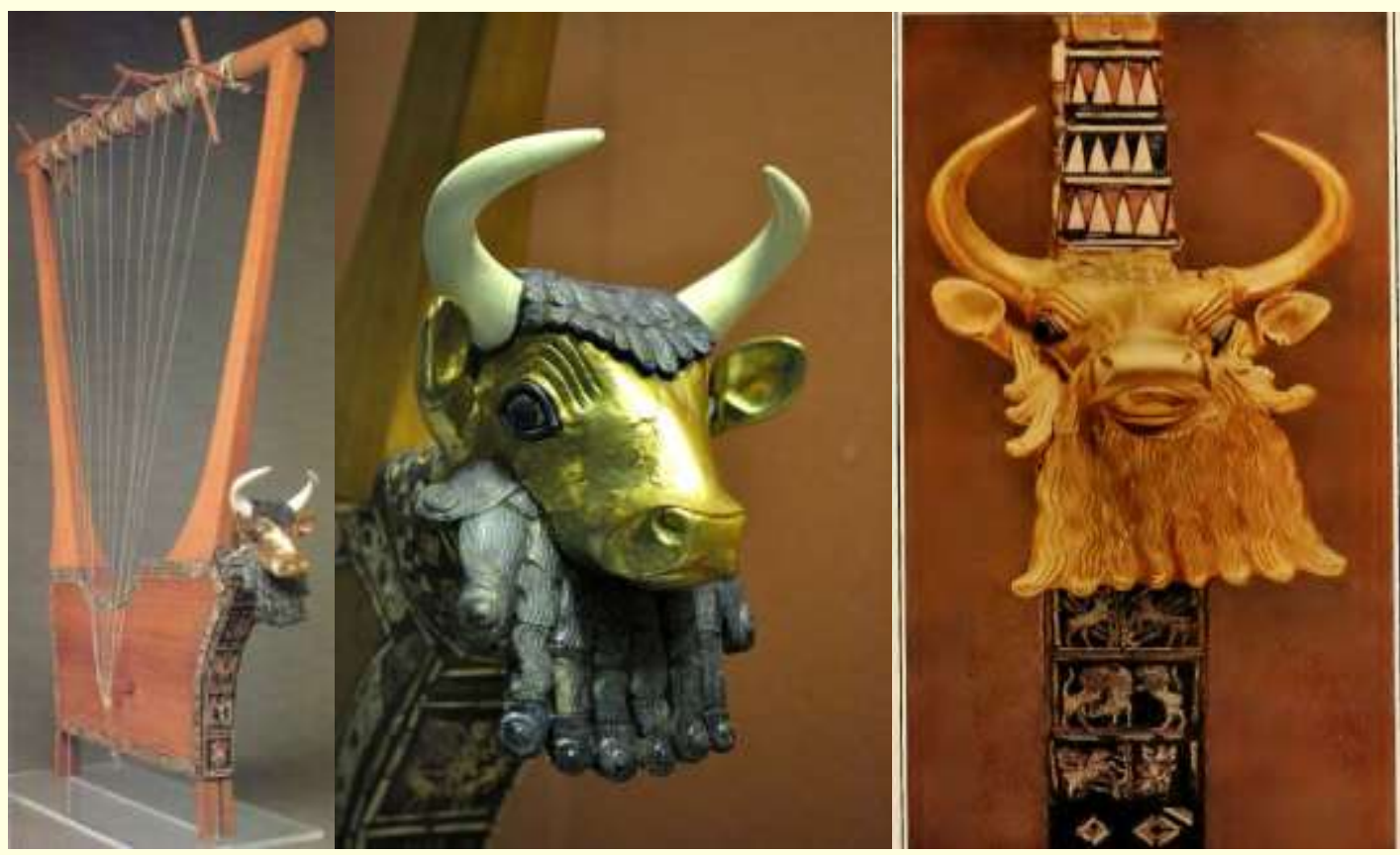

Şekil 15. Ur Kraliyet Mezarlığı'nda Woolley tarafından çıkarılan Lir (Roaf 1996: 45; Wooley 1934: Res.115 ).22,25 
Kraliçe Puabi'in mezarında iki arp daha bulundu. Arpın özelliği, dış hatlarının üçgen olmasıdır; teller ses kutusunun karşııında değil, bir ucundan fışkıran bir çıkıntılı kola doğru yükselir; bu kolda ayar pimleri yer alır (Şekil 16). ${ }^{22}$

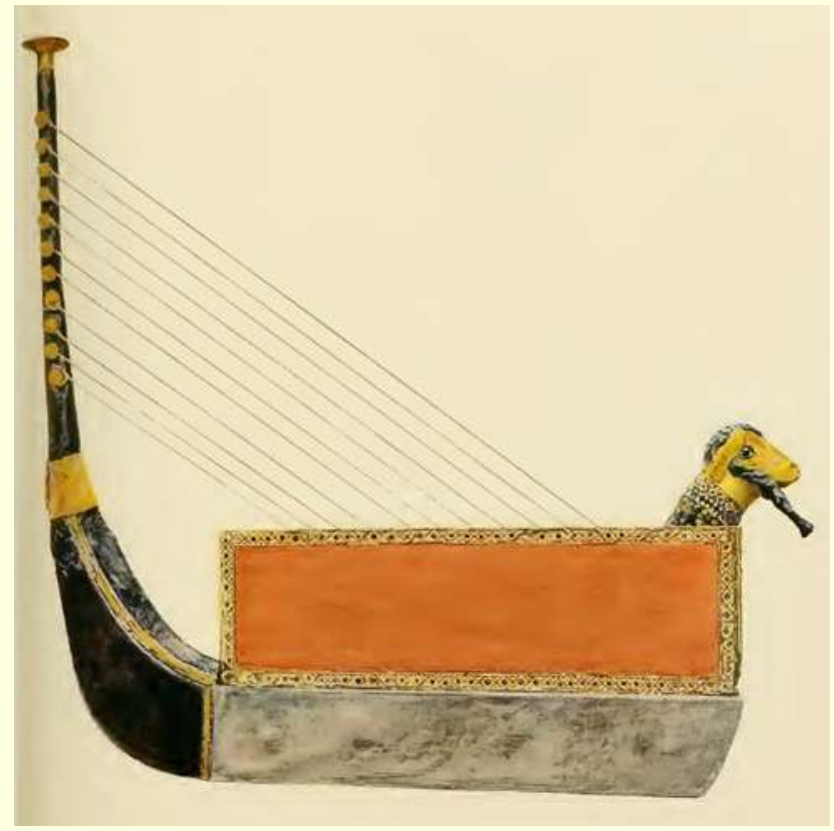

Şekil 16. Kraliçe Puabi'nin restore edilmiş harp müzik aleti (Wooley 1934: Res. 109). ${ }^{22}$

Dünyanın en eski yazılı sözlü müziği, Ugarit'teki çivi yazılı tabletlerde bulunan ve MÖ 2. binyılın ortalarına tarihlenen tablete geçen Hurri ilahileridir. Hepsi aynı akort veya modda bestelenmiş metin (Hurri dilinde) "tanrılara şarkı" adı altında müzikal bir besteyi içeriyordu. ${ }^{24}$

\subsection{Antikçağda Müzik}

Arkaik ve klasik dönemde müzik geleneksel olarak dilden dile aktarılarak söylenir ve çalınırdı. Klasik dönemde müzikler ölen sporcular ya da savaşlarda ölen kahramanlar için bestelenirdi. MÖ 5. yüzyılın Atina'sında gelişen, gerçek bir klasik gelenek (rekabet) halindeydi. Bu geleneğin en büyük belgesi, MÖ 405 'te üretilen Aristophanes Kurbağalarıdır. MÖ 404'te Atina yenilgi ve bozgunla iç içeydi. Dördüncü yüzyılda okul ve tiyatrodaki müzik bilgisi rezervleri ihmal edildi. ${ }^{26}$ Antik çağdaki geniş müzik üretiminin dışında, çoğunluğu papirüs ve taş buluntularından oluşmak üzere yirmiye yaklaşık yazılı müzik parçaları vardır. MÖ 4. yüzyılda klasik müzik eğitimden bir şeyler vermeye çalışan Platon, müzik öğretmenlere aşağıdaki tavsiyelerde bulunur: ... Lir tellerinin netliği için, diğer müzik aletleri ile birlikte kullanılmalıdır. Müzik aletini çalan ve besteleyen kişi birlikte çalışmalıdır . ${ }^{26}$

Antik Grek'in en önemli enstrümanlarından biri olan aulos; sporda, savaşa hazırlık ve yarışma sahnelerinde sürekli olarak betimlenmiştir (Şekil 17). Antik Grek'te sıklıkla tasvir edilen diğer enstrümanlar kithara (aşağıda soldaki resim), lirdir. Greklerde müziğin önemi mitolojik olarak konulara yerleşmiştir. Bir yarışmada Apollon çok iyi lir çalarken rakibi Marsyas ise flüt çalmaktaydı. ${ }^{27}$ 

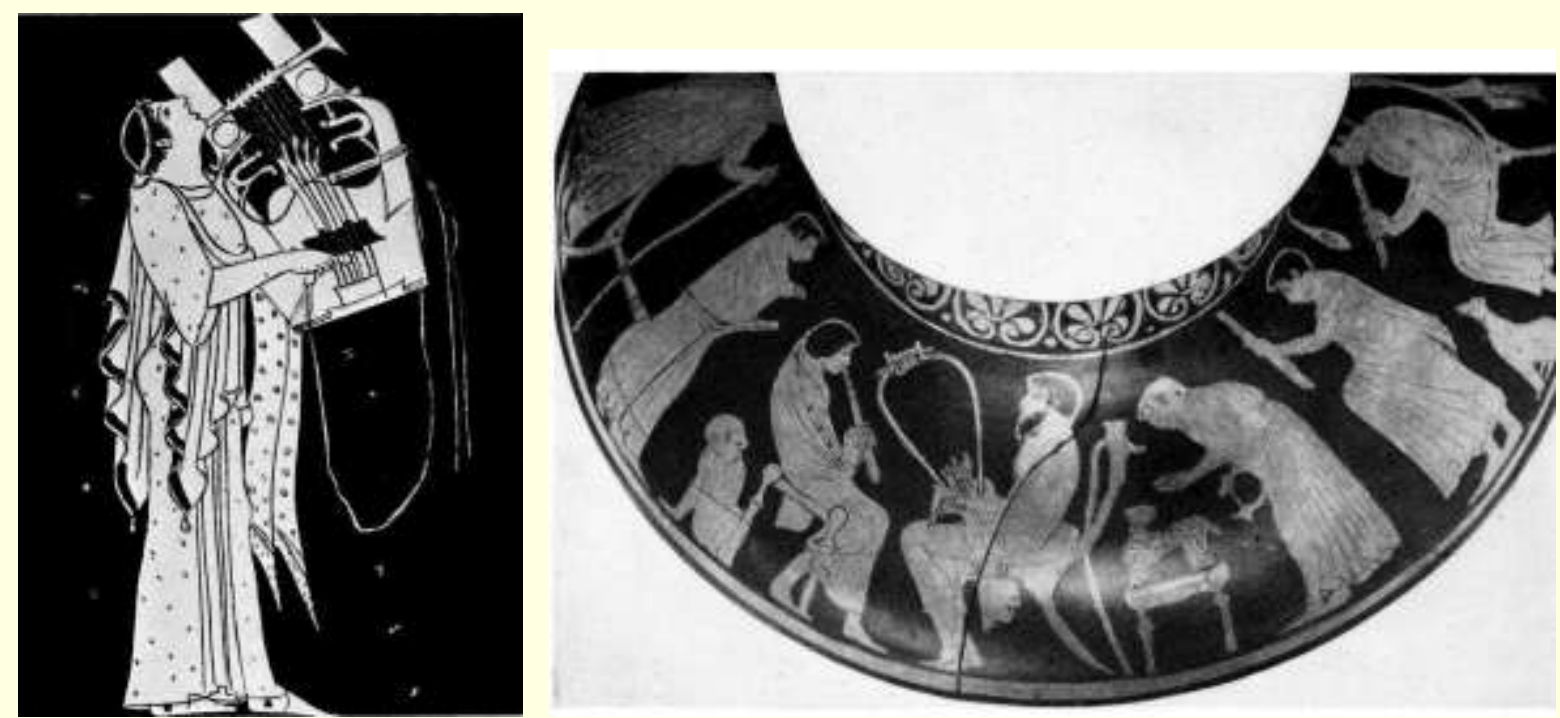

Şekil 17. Solda kithara çalan şarkıcı; sağda Lir ve çift aulos öğretisini gösteren bir Grek müzik okulu-MÖ 5. yüzyılın başları (Henderson 1957: 352). ${ }^{26}$

\section{TARTIŞMA VE SONUÇ}

Müzik için enstrüman üretimi ve çalınması, arkeolojik kayıtlarda bulunan kanıt örneklerine dayanarak Üst Paleolitik dönemde başladığına göre müzik yapma geleneği çok eskidir; mimari yapıdaki evlerden, pişmiş toprak kaplar ve figürinlerden, hayvanların evcilleştirmesinden, yerleşik yaşama geçişten ve yazıdan da daha eski bir geçmişe sahiptir. Coğrafi ve kronolojik bağlamlardan bağımsız olarak kuşların kanat kemikleri özellikle de ulnaeları, boru tipi enstrümanlar yapmak için en çok tercih edilen hammadde olmuştur. Kuşların ulnaesı (insan iskeletindeki dirsek olarak bilinir), aerofon yapmak için idealdir. Uzun, ince, içi boş ve hafiftirler. Proksimal ve distal uçları çıkarılarak, hava üflenebilen ve ses üretilebilen bir tüp bırakıı.ır. Paleolitik Dönem Avrupa'da mağaralarda ele geçen flütler bilim dünyasında hala tartışılmaktadırlar. Bazı bilim adamları bunların flüt olmadığı yönünde görüş bildirmektedirler. Tarihöncesi flütler deneysel arkeoloji yönünden bilim adamlarınca bunların flüt olduğuna yönelik çalışmalarla hala desteklenmeye devam etmektedir. Paleolitik dönemde üretilen kemik flütler Antik Grek uygarlığında mitolojilere de konu olmuştur. Bununla birlikte, atalarımızın arkeolojik kazılarda ortaya çıkamayan ahşap veya kamış gibi daha dayanaksız diğer hammaddeleri kullanmaları da muhtemeldir dâhilindedir. Tunç Çağında müzik daha çok insan hayatında yer edinmiştir. Kraliçe Puabi'nin mezarında çok sayıda müzik enstrümanı ortaya çıkarılmıştır. Mezopotamya'da müzik her ne kadar erkek mesleği olarak geçse de adına heykeller diktirilen kadın müzisyenler de yer almaktadır. Antik Grek'te müzik mitolojik öğelere sıkça girmiş, yarışma, ziyafet, savaşa hazırlık gibi bir çok konuda enstrümanlar tasvir edilmiştir.

\section{KAYNAKLAR}

1.Morley I. The Evolutionary Origins And Archaeology Of Music or An Investigation into the Prehistory of Human Musical Capacities and Behaviours, Using Archaeological, Anthropological, Cognitive and Behavioural Evidence, Faculty of Archaeology and Anthropology of Cambridge University, Doktora Tezi; Cambridge: 2003

2.D'errico F,et al. Middle Palaeolithic origin of music? Using cave-bear bone accumulations to assess the Divje Babe I bone 'flute'. Antiquity 1998; 72: 65-79.

3.Killin A. The origins of music: evidence, theory, and prospects. Music \& Science 2018; 1:1-23.

4.Kunej D, Turk I. (2000). New perspectives on the beginnings of music: Archeological and musicological analysis of a middle paleolithic bone "flute." In: Wallin N, Merker B, Brown S. Editors. The origins of music. Cambridge: MIT Press; 2000. pp: 235-269.

5.Atema J. Old Bone Fluttes. Pan Magazine 2004; 11: 18-23.

6.Atema J. Musical origins and the stone age evolution of flutes. Acoustics Today 2014; 10(3): 25-34.

7.Gill F. Flute Lines: Experiencing Reconstructions Concerning Music [Internet] [Dissertation]. 2012. Available from: http://urn.kb.se/resolve?urn=urn:nbn:se:Inu:diva-27479. 
8.Turk M, Turk I, Otte M. The Neanderthal Musical Instrument from Divje Babe I Cave (Slovenia): A Critical Review of the Discussion. Applied Sciences. 2020; 10(4):1226.

9.Münzel SC, Seeberger F, Hein W. The Geissenklösterle Flute-Discovery, Experiments, Reconstruction. Hickmann E, Kilmer AD, Eichmann R, editors. Studien zur Musikarchaologie III; Archaologie früher Klangerzeugung und Tonordnung; Musikarchaologie in der Agais und Anatolien. Orient-Archaologie Bd. 10. Verlag Marie Leidorf GmbH: Rahden/Westfalen; 2002. pp: 107-118.

10. Davis SJM, Moreno-García M. Of metapodials, measurements and music: eight years of miscellaneous zooarchaeological discoveries at the IPA, Lisbon. O Arqueólogo Português 2007; 25:9-165.

11. Benito CG, Gracia MA, Perez CM. (2016). Reproduction of an Upper Palaeolithic Bird-Bone Pipe with Finger Holes from Isturitz First Experiments. In: Eichmann R, Koch LC, Jianjun F, editors. Sound-Object-Culture-History. Papers from the 9th Symposium of the ISGMA at the Ethnological Museum, State Museums Berlin: 09-12 Eylül, 2014. Orient-Archäologie 37, Studien zur Musikarchäologie X, 2016. pp: 213-223.

12. Brade C. The Prehistoric Flute-Did It Exist?. The Galpin Society Journal 1982; 35 (1): 138-150.

13. Conard N, Malina M, Münzel SC. New flutes document the earliest musical tradition in southwestern Germany. Nature 4602009 ; 737-740.

14. Conard N, Malina M. New evidence for the origins of music from the caves of the Swabian Jura. In: Both AA, Eichmann R, Hickmann E, \& Koch LCh, editors. Orient-Archaologie Band 22. Studien zur Musikarchaologie VI. Rahden, Germany: Verlag Marie Leidorf Gmbh; 2008.pp: 13-22.

15. Kuhn S, Stiner M. The earliest Aurignacian of Riparo Mochi (Liguria, Italy). Current Anthropology 1998; 39 (3), $175-189$.

16. Morley I. Mousterian musicianship? The case of the Divje babe I bone. Oxford Journal of Archaeology 2006; 25(4), $317-333$.

17. Odar B. Potocka zijavka Fertility rites in The Raining cave. Studia mythological Slavica XV 2012; 9-34.

18. Merriam A. The Anthropology of Music. Chicago: North Western University Press: 1964

19. Zhang J, et al. Oldest playable musical instruments found at Jiahu early Neolithic site in China. Nature 401 1999; $366-368$.

20. Benito CG. Wind from the Sky, Wind from the Earth. The Earliest Bone Pipes and Whistles. De Angeli S. Et al. editors. Music and Sound in Ancient Europe Contributions from the European Music Archaeology Project. Roma: Emap; 2018. pp: 26-29.

21. Duchesne-Guillemin M A. Hurrian Musical Score from Ugarit: the Discovery of Mesopotamian Music. Malibu:Undena Publications: 1984.

22. Woolley CL. Ur Excavations Volume II The Royal Cemetery. A Report on the Predynastic ans Sargonid Graves Excavated Between 1926 and 1931 (Text and Plates). London: Oxford University Press: 1934.

23. Van Dijk RM. Mesopotamian Early Dyanstic Bull-Lyres. XIV Jornadas Interescuelas/Departamentos de Historia. Departamento de Historia de la Facultad de Filosofía y Letras. Mendoza: Universidad Nacional de Cuyo: 2013.

24. Duchesne-Guillemin M. Music in Ancient Mesopotamia and Egypt. World Archaeology 1981; 12(3), 287-297.

25. Roaf M. Atlaslı Büyük Uygarlıklar Ansiklopedisi Mezopotamya ve Eski Yakındoğu (9) (Çeviren: Zülal Kılıç) İstanbul: İletişim Yayınları: 1996.

26. Henderson I. Ancient Greek Music. In: Wellesz E.editor. Ancient and Oriental Music London: Oxford University Press: 1957.

27. Erhat A. Mitoloji Sözlüğü. İstanbul: Remzi Kitapevi: 1996. 